\title{
An Analysis of Roland Barthes' Semiotics (a Study of Islamic Religious Commodification in Resik V Perhiasanku Advertisement)
}

\author{
K Koirudin ${ }^{1}$, S K Habsari², D T Ardiyanto ${ }^{3}$ \\ $\left\{{ }^{1}\right.$ kolik.tb@gmail.com²skhabsari@staff.uns.ac.id ${ }^{3}$ denytherockies@gmail.com\} \\ 1,2,3 Universitas Sebelas Maret
}

\begin{abstract}
This study utilizes a socially critical approach to observe how the Islamic values are used as a medium for delivering messages which is seen to be of particular interest to its believers, which will then stimulate the sense of sympathy to the product being advertised. Resik $V$ Khasiat Manjakani Whitening Versi Perhiasanku is one of the advertisements which use religious values to deliver the product's message. Moslems are the majority population in Indonesia which become a promising market for product sales. The values believed by the moslems are transformed into exchange values by the capital owners to get maximum profits. Moslem women's imagination of the concept of shalehah (pious) wife and sakinah (tranquil) family is revived so they are attracted to buy the product. The advertisement subtly says that by using the product, they will become shalehah wives, it will strengthen the relationship with their spouses, and it will create a sakinah family. The religion's function of use is turned into exchange values by the capital owners to obtain profits. The problem focus in this research is to unveil the commodification process of religion by using Roland Barthes' semiotics analysis. The result of the study is a common phenomenon nowadays, the demands to use halal-labeled products as an identity of religious people who obey their God will always exist has transformed into everyday life, it is intepreted by the capital owners, therefore they wrap their products with religious values so that it can attract maximum profits.
\end{abstract}

Keywords: commodification, Islam, advertisement media

\section{Introduction}

Advertisements in television have constructed the reality and influence one's view of a value. The value is changed or used to gain profits unilaterally[1]. An advertisement is deliberately made in the communication media with the aim of gaining profits or it can be said as one of the commodities in the mass media[2]. When religious values are drawn to this area, it can be said that there is a change or diversion of religious value into exchange value. In this context, the religion becomes a very tempting commodity, considering that it is an identity that transcends the boundaries of ethnic, race, and nation. 
The advertisement's message delivery by using religious approach in the television has taken a position which is believed to attract audiences' attention. Religious approach is a technique to deliver an advertisement's message utilizing various signs regarding the noble religious teachings, it can also use a representative and devout religious figure. The purpose is to attract the attention and give special empathy to public to buy the product being advertised. The values that exist in a religion are often "mass-produced" to become commodities to gain profits. Whether it is realized or not, advertisements that include religion have been very common nowadays. The context of society in the digital era is basically intellectual workers who have exchange values; it makes the society has some degree of autonomy in an information economy where an idea has been re-verified, public in nature, and commodified[3].

The religious values are seen as moral and ethical guides by their believers. Those values have universal meaning, transcends the time and space boundaries, and are always relevant in all context. Those values are perceived as something sacred that should be practiced by the believers with devotion. There are claims that there is a reward of glory to those who practice the values, and there is a humiliation for those who do not practice them. However, when those concepts are brought to advertisement media, there is a shift of the functional use of a religion into exchange value. Religious values are commodified to gain unilateral interest, instead of the interests of followers of that religion. The religious values are used as a medium for delivering messages which is seen to be of particular interest to its believers, which will then stimulate the sense of sympathy to the product being advertised. It is uncontested that today there are shifts of religious values into economic transactions, especially when the symbols of faith are used to market the Islamic-related products[4].

The meaning in commodification is not only based on goods and services production that are being traded, but how the goods distribution and consumption are available, as expressed by Fairclough[5], that commodification is a process. The social domains and institution which do not only focus in producing commodities in the narrow economic sense of the goods to be sold, but how the focus is organized and conceptualized in terms of commodity production, distribution, and consumption. Commodification is often criticized with the reason that some things should not be sold and treated as if they were commodities[6].

In addition, Marx mentioned that commodification has made everything possible to be measured and used because everything has their own price. The bourgeois society, in short, reduces the humanity value into something of economic value and they homogenize the differences which should become the characteristics of everyday life and become public's commodification[7]. Generally, according to Vincent Mosco, the theory of political economy is a study of social relations, especially the strength of those relationships which reciprocally include the production, distribution and consumption processes of products that have been produced. This theory surfaced due to the big influence of mass media on the changes in society life[8]. This departs from the assumption that mass media links the world of production and consumption. Through the message spread by the advertisements in mass media, increased sales of products and services are very likely to occur when the audiences are affected by messages displayed on the mass media[9].

Commodification is defined by Karl Marx as the 'ideology' residing behind the media. According to him, the word can be interpreted as an effort to prioritize profit gains compared to other objectives[10]. Resik V Khasiat Manjakani Whitening Versi Perhiasanku is one of the advertisements that applies the commodification process. The advertisement uses two Moslem celebrities, Dude Herlino and Alyssa Soebandono. Public sees the couple as religious public figure who devout to Islamic values. The product in Resik V Khasiat Manjakani Whitening 
(Perhiasanku) advertisement is a feminine cleansing product which uses jicama which uses special compound from Persia as its ingredients.

The preeminence of the advertisement is that its plot shows a celebrity couple, Dude Herlino and Alyssa Soebandono. The narrative structure such as story lines, characterizations, actions, and other narrative elements are the ways to communicate the possibilities of meaning. It is common for the advertisers to use all sign elements to enhance the message's attractiveness in the competition for advertising messages in the mass media[11]. The advertisement explains the secret of a shalehah wife as the most beautiful jewelry, and it conveys that Resik V Khasiat Manjakani Whitening Versi Perhiasanku is the secret to sakina family.

\section{Research Method}

This is a qualitative research which data have natural characteristics and is descriptive where the process is more important than the results. The analysis were done using induction, in which the researcher begins to approach the hypothesis first. In addition, meaning is essential in this research. The data were divided into primary and secondary data. The primary data consisted of visual data, narration and celebrities displayed in Resik V Khasiat Manjakani Whitening Versi Perhiasanku advertisement. The secondary data were books, journals, and documents related to the topic of research. The primary data source was Resik V Khasiat Manjakani Whitening Versi Perhiasanku.

The data analysis technique used Roland Barthes' semiotics analysis. In his analysis, Barthes wanted to show what is called as order of signification[12], where it has denotative and connotation meaning which will then create a myth for the sign receiver[13]. The denotative meaning is the meaning according to what exists in the reality or it can also be called as dictionary meaning[14]. The connotation meaning is a multiple meaning that appears in accordance with personal and cultural experience of the sign receiver. The meaning shows that that there are interactions between the text and the reader[15], and between the text convention and the conventions experienced and expected by the reader or the sign receiver. This theory states that the sentence will be perceived differently by people who are in different situation and condition.

\section{SIGN II $\Longrightarrow$ MYTH \\ $($ SIGN I) $\Longrightarrow$ SIGNIFIER II $\quad$ SIGNIFIED II $\longrightarrow$ CONNOTATION \\ SIGNIFIER I SIGNIFIED I $\longrightarrow$}

\section{Results And Discussion}

\subsection{Product's Profile and Synopsis of Resik V Advertisement}

Resik $V$ is a feminine cleansing product produced by PT Kino Indonesia Tbk. This is a feminine cleansing product with the best combination of natural ingredients suited to the needs of modern women. It is a practical and sollutive product processed from $100 \%$ natural herbal extract ingredients and has received a halal certification from Majelis Ulama Indonesia (Indonesian Ulema Council). 
Resik V Khasiat Manjakani Whitening is produced by using jicama as its main ingredient and manjakani (Quercus Infectoria) from Persia. This product has two functions: to tighten and to whiten. The Senior Public Relation Manager of PT Kino Indonesia Tbk, Yuna Eka Kristina, stated that because of the two functions, Resik $V$ Manjakani Whitening has a great sales contribution in Indonesia. This product offers two kinds of packaging, a $50 \mathrm{ml}$ bottle (1 carton contains 72 bottles) and a $90 \mathrm{ml}$ and $200 \mathrm{ml}$ bottle (1 carton contains 36 bottles).

Resik $V$ advertisement begins with a jilbab (veiled) woman who is looking in a mirror then a man from appears from behind, saying that a shalehah (pious wife) is the most beautiful jewelry. The man says to the woman that in his eyes, she is always beautiful. The woman then tells that Resik $V$ Manjakani Whitening is her secret. It is said that Resik $V$ is made from selected Persian manjakani (Quercus Infectoria) and jicama which is proven to brighten and tighten the feminine area two times better. The product brightens herself and strengthen her marriage. In the end of the advertisement, the man says that Resik $V$ Khasiat Manjakani Whitening is the secret to sakinah (tranquil) family. The 30-seconds advertisement ends with a dominantly white background and the white clothes worn by the man and the woman are Muslim's clothes in general. The theme of this advertisement is my jewelry.

\subsection{Islamic Religious Commodification in Resik $V$ Advertisement}

In order to unveil the commodification of Islam in Resik $V$ advertisement by using Roland Barthes' semiotics analysis, some signs in the advertisement are takent to read and show the commodification process that takes place. Those signs are shown below:

\subsubsection{Clothes}

a. Denotative Meaning. The clothings used by the celebrities in this advertisement have white nuance, the woman wears fashionable jilbab (veil), and the man looks masculine and well-dressed.

b. Connotative Meaning. Showing self-purity and obedience of religious teachings, but at the same time, the celebrities still become a part of modern society that are fashionable and trendy.

c. Meaning of Myth. The myth for the consumers is that if they use Resik $V$ product, then they will be like the people in the advertisement, who are pious, obedient to religion, yet fashionable, modern and trendy at the same time.

Pious, religious, and modern people use Resik $V$

White clothes, fashionable jilbab (veil), and Self purity, obedience to religion, and masculine man

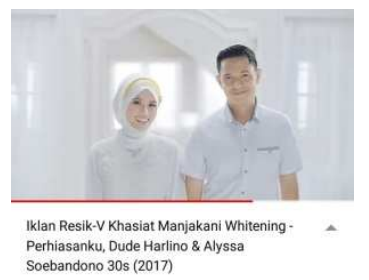

White-nuance

being a part of modern society that is fashionable and trendy at the same time

clothes, fashionable-

veiled woman, and

well-dressed

masculine man.

\subsubsection{Narration}

a. Denotative Meaning. The narration in this advertisement lies on the emphasis of the phrase "perhiasan terindah adalah istri salehah" (the most beautiful jewelry is a pious wife); "Resik $V$ cerahkan diriku, eratkan pernikahanku" (Resik $V$ brightens me, 
strengthen my marriage); "Resik V rahasia keluarga sakinah" (Resik $V$, the secret to tranquil family).

b. Connotative Meaning. Showing that Resik $V$ product has multiple benefits: cleansing and brigthening the feminine area, it can also strengthen marriage and become the secret of a sakina (tranquil) family.

c. Meaning of Myth. Feminine area is the secret to become a shalehah wife who can tighten a marriage relationship, and create a sakina family. You should use Resik $V$ to brighten and cleanse your feminine area.

By using Resik $V$ products, you are a shalehah (pious) wife.

Shalehah's wife, sunny feminine area, sakinah family.

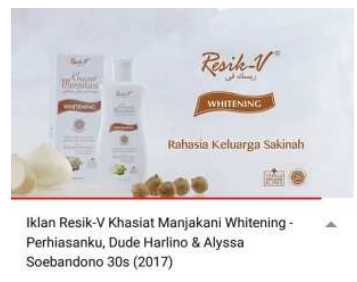

"Perhiasan terindah adalah istri salehah"

(the most beautiful jewelry is a pious wife);

"Resik V cerahkan diriku, eratkan pernikahanku" (Resik $V$ brightens me, strengthen my marriage); "Resik $V$ rahasia keluarga sakinah" (Resik V, the secret to tranquil family).
Resik $V$ product has multiple benefits: cleansing and brigthening the feminine area, it can also strengthen marriage and become the secret of a sakinah (tranquil) family.

\subsubsection{Celebrities}

a. Denotative Meaning. The celebrity couple displayed on this advertisement is Dude Herlino dan Alyssa Soebandono. They are young celebrity couple who are seen religious or devout to Islamic values by the public.

b. Connotative Meaning. Religious celebrity couple uses Resik V.

c. Meaning of Myth. You should use Resik $V$ if you want to be like Dude Herlino and Alyssa Soebandono couple.

You should use Resik $V$ if you want to be like Dude Herlino and Alyssa Soebandono couple.

Young celebrity couple who are seen religious Religious celebrity couple uses Resik $V$. or devout to Islamic values by the public.

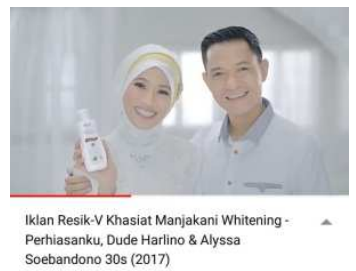

3.3 Discussion
Dude Herlino and

Alyssa Soebandono, young celebrity couple who are seen religious or devout to Islamic values by the public. 
For Muslims, popular culture in the recent era is one struggle for identity. It may form or challenge ideas about Islam, piety, worldview or even gender perception[16]. It is a marker of a person's social status and identity, considering that he has become part of a broad consumption culture. Those things can not be separated from the role of Muslim intellectuals and creative workers such as filmmakers and advertisers who massively campaign Islamic symbols and values through their works.

Around the 1980s, 1990s and post 1998, structural transformation took place in Indonesia contributed to the emergence of what is called Islamic pop culture. It is related to the emergence of new middle class-Muslims who want to explore the symbols and values of piety through consumption and identity in the public sphere[17]. It then makes pop culture a fertile ground for aesthetics or media workers through the products they sell. The Islamic pop culture started with the surge in popularity of religious commodities such as the digital Koran, Islamic clothing and CDs of Islamic speech during the 1990s and early 2000s.

Raharjo mentioned the term "Islamic Pop" emerges due to the modernization amidst the Islamic society that practices Islamic cultural values[18]. It is undeniable that modernity is in line with liberalism, hedonism, and westernization, which makes Europe, America and East Asia the leading countries. At the same time, Muslims must still maintain their Islamic values. What happens then is the symbolization of religion in public spaces as a sign of devotion and modernity. Even though Indonesian Islamic pop culture is only at the aspect of mass culture production aspects the main construction among Muslims is to show their identity through the Islamic products they use[19].

Likewise, the commodification of Islamic values in Resik V Khasiat Manjakani Whitening Versi Perhiasanku illustrates that Pop Islam opens opportunities for capital owners to market their products in an identity struggle among Muslims. A product can always image the consumers, such as their aspect of devotion. It is then seen as a promising opportunity by the capital owners [20].

\section{Conclusion}

The main motivation of Resik $V$ Khasiat Manjakani Whitening Versi Perhiasanku by internalizing the Islamic values is to attract Moslems' sympathy. Moslems are the majority population of Indonesia, which become a promising target market for product sales. The values believed by moslems are transformed into exchange value by the capital owners to gain as much profits as possible. This is a practice of commodification where the functional use is turned into exchange value. There are commodification disguises in the advertisement, in which the product's advertisement says that it has two functions, to tighten and to brighten. A moslem woman's imagination about the concept of shalehah wife and sakinah family, thus attracting them to use the product. The advertisement subtly says that by using the product, the women consumers will become shalehah wives, and the relationships with their spouses and family will be strengthened, and it creates a sakinah (tranquil) family. In addition, if the consumers want to become like Dude Herlino and Alyssa Soebandono couple, then they should use Resik $V$. The functional use of the religion, in this point, is turned into exchange rate by the capital owners for individual's or company's interest, and not for the Moslem's interest in general. Even though such commodification process has become a common phenomenon nowadays, the demands to use halal-labeled products as an identity of religious people who obey their God will always exist. Obedience to the values that exist in the religion 
has transformed into everyday life. It is intepreted by the capital owners, therefore they wrap their products with religious values so that it can attract maximum profits.

\section{References}

[1] R. Widyatama, Bias Gender dalam Iklan Televisi. Yogyakarta: Media Pressindo, 2006.

[2] A. Musthofa, "Komodifikasi Kemiskinan oleh Media Televisi," J. Makna, vol. 3, no. 1, pp. 1-14, 2012.

[3] Y. N. Labas and D. I. Yasmine, "Komodifikasi di Era Masyarakat Jejaring: Studi Kasus YouTube Indonesia,” J. Pemikir. Sosiol., vol. 4, no. 2, pp. 104-119, 2017.

[4] R. Abdur, "Komodifikasi Islam (Kesalehan dan Pergulatan Identitas di Ruang Publik)," $J$. Dakwah, vol. XIV, no. 2, pp. 199-212, 2013.

[5] Fairclough, Critical Discourse Analysis: The Critical Study of Language, 2nd New ed. London: Taylor \& Francis Ltd, 2010.

[6] V. Mosco, The Political Economy of Communication, 2nd Revise. Thousand Oaks: SAGE Publications Inc, 2009.

[7] Pristiwanto, "Komodifikasi dan Pergeseran Makna Kearifan Lokal: Studi Kasus Upacara Tradisional Tangkap Ikan Mane'e pada Masyarakat di Perbatasan Indonesia-Philipina," Universitas Airlangga, 2011.

[8] D. Fadillah, "Komodifikasi Seksual dalam Kepentingan Ekonomi Portal Berita Online," Informasi, vol. 45, no. 2, pp. 155-162, 2016.

[9] W. Muktiyo, "Komodifikasi Budaya dalam Konstruksi Realitas Media Massa," MIMBAR, J. Sos. dan Pembang., vol. 31, no. 1, pp. 113-122, 2015.

[10] G. Burton, Media dan Budaya Populer. Yogyakarta: Jalasutra, 2012.

[11] P. W. Fernandez, "Komodifikasi Perempuan dalam Iklan Televisi," J. Ilmu Komun., vol. 8, no. 1, pp. 60-80, 2013.

[12] M. T. Ishak and M. M. Sir, "Pembacaan Kode Semiotika Roland Barthes Terhadap Bangunan Arsitektur Katedral Evry di Prancis Karya Mario Botta," vol. 2, no. 1, pp. 85-92, 2005.

[13] K. Budiman, Jejaring Tanda-Tanda: Strukturalisme dan Semiotik dalam Kritik Kebudayaan. Magelang: Indonesiatera, 2004.

[14] R. Barthes, Mitologi. Bantul: Kreasi Wacana, 2004.

[15] O. Zaimar, Semiotika dan Penerapannya dalam Karya Sastra. Jakarta: Pusat Bahasa, 2008.

[16] J. B. Hoesterey and M. Clark, "Film Islami: Gender, Piety and Pop Culture in Post-Authoritarian Indonesia," Asian Stud. Rev., vol. 36, no. 2, pp. 207-226, 2012.

[17] J. D. Howell, Expressing Islam: Religious Life and Politics in Indonesia. Singapore: Institute of Southeast Asian Studies, 2008.

[18] W. R. Jati, "Islam Populer Sebagai Pencarian Identitas Muslim Kelas Menengah Indonesia," $J$. Tasawuf dan Pemikiran Islam, vol. 13, no. 3, pp. 139-163, 2015.

[19] H. Ariel, Budaya Populer di Indonesia: Mencairnya Identitas Pasca-Orde Baru. Yogyakarta: Jalasutra, 2012.

[20] K. Saddhono, "Language and superdiversity: Indonesians knowledging at home and abroad. By Zane Goebel." Soc. Stu. vol. 12 no.1 pp. 113-118, 2018 